\title{
GLOBAL DESIGNS, POSTCOLONIAL CRITIQUES: RETHINKING CANADA IN DIALOGUE WITH DIASPORA ${ }^{1}$
}

\section{Diana Brydon}

In the special millennial issue of Essays on Canadian Writing, Imre Szeman writes of the "shock of recognition" he experienced on first reading Roberto Schwarz's Misplaced Ideas: Essays on Brazilian Culture. I felt a similar shock in belatedly discovering Schwarz's work while compiling an anthology, Postcolonialism: Key Concepts, to make more widely available major works contributing to the definition of the postcolonial field throughout the last century. Although space was limited, Brazilian writer Oswald de Andrade and Brazilian theorist Roberto Schwarz were clearly essential to this project. Neil Larsen, one of the few postcolonial critics to write extensively about Schwarz's importance for postcolonial theory, concludes from his various analyses of Schwarz that "A genuine dialogue with the South might, that is, have to start by re-authorizing the South not only to speak to us of itself but to speak to the North about theory - i.e. about ourselves as well - in the very process of speaking of itself" (Determinations 77). While I question Larsen's implication that authorizing power resides in the United States and that re-authorization from that source is necessary before genuine dialogue can begin, I also recognize (as he does) the material and

\begin{tabular}{|l|l|l|l|l|}
\hline Ilha do Desterro & Florianópolis & $n^{\circ} 40$ & p.061-084 & jan./jun. 2001 \\
\hline
\end{tabular}


psychological realities from which such assumptions stem because Canadian theorizing, although "Northern," participates uneasily in these exchanges. Establishing genuine dialogue, the aim of this special issue (as I understand it), is also the goal of this paper.

Larsen and Szeman begin this process of genuine dialogue by following various strains in Schwarz's thought, Larsen in relation to the United States and Szeman to Canada. Both find in him a salutary materialist insistence, an evocative use of apparently simple language (in translation) for complex thinking about what he terms "misplaced ideas," and valuable insight into the cultural belatedness and inauthenticity experienced by a settler society or "neo-Europe" (Alfred Crosby's term, in Ecological Imperialism, for those colonies made over in the European image). Larsen's recognition that Schwarz "thinks of the 'national' as a product - social, economic, historical - of the international, the global" leads him to conclude: "The part is thought through the whole" (Reading 214). Such a shifting of the analytical frame, from thinking nation as ground toward thinking nation as product, begins to answer the question of how to think culture beyond and not just through the nation. Szeman's essay unpacks how such a rethinking of national/global relations may enable asking harder questions "about the political and social function of Canadian literature with respect to everyday life in Canada, especially as expressed in class terms" (193), thereby demonstrating how cultural materialist postcolonial theory may establish a new basis for thinking about Canadian and Brazilian literary studies comparatively. In colonial times, as Renata Wasserman points out in Exotic Nations, readers and authors "took it for granted that literature would serve nationality" (5). Even in contemporary postcolonial theory, as indicated in the title of Homi K. Bhabha's Nation and Narration, "a necessary connection between writing and nationality" (5) is often posited. Globalization and diaspora theory challenge that necessary connection.

This paper follows the thread unravelled by Schwarz, Larsen, Szeman and Wasserman in considering challenges facing postcolonial 
theories of writing in the Americas under current conditions of global capitalism. In "Re-routing the Black Atlantic" and "Detour Canada: Rerouting the Black Atlantic, Reconfiguring the Postcolonial, " I discuss a series of Canadian texts dedicated to exploring the implications for Canada of the paradigm developed by Paul Gilroy in The Black Atlantic. What are the implications of Gilroy's thesis for thinking about Brazil, and about Brazil and Canada together? In Brutality Garden: Tropicalia and the Emergence of a Brazilian Counterculture, Christopher Dunn analyses how such a shift in paradigm, as exemplified in a range of "commodified forms of African American popular culture throughout the Third World," challenges "the nationalist ethos of brasilidade, which tended to obfuscate racial discrimination and inequality by exalting the mestiçoethos" (178). Arguing that Tropicalia, "This alliance between musicians from Bahia, a primary locus of Afro-Brazilian culture, and from São Paulo, the largest, most industrialized Brazilian city, proved to be a potent combination and has had a lasting effect on Brazilian popular music and other arts" (2), he uses their work to create a cultural history of Brazil with important implications for Canadian debates. The possibility of reconfiguring the black Atlantic as a vast and striated "contact zone" (Mary Louise Pratt) in which Brazil and Canada meet provides me with the rationale for my choice of two texts for examination in this paper, fictions which initiate that genuine sense of dialogue that will be necessary if we are to understand how national dreams may lead to global awakenings.

As frameworks for understanding the world, both postcolonialism (as an analytical category and a decolonizing research agenda) and Canada (as a nation-state based on the theft of Indigenous land) require continual vigilance and renovation. The perspective developed here derives from the conversations developing among Indigenous, settler and international postcolonialisms of various kinds. Chela Sandoval argues: "To understand present globalization as a move from 'modernism' to 'postmodernism' makes invisible the de-colonial process of the last five hundred years...That is why there has been a 
movement to understand contemporary globalization that shifts from mapping the global against a 'modernism/postmodernism mode' to a 'colonial/postcolonial model" (fn.12 190). The January 2001 issue of PMLA, devoted to the special topic of "Globalizing Literary Studies," while it asks important questions about the implications of globalization models for shaping literary study, also shows why Sandoval's shift to the colonial/postcolonial model is necessary. As Balachandra Rajan writes in a letter responding to this PMLA special issue, "Empires have often dreamed of universality. Globalization appropriates this dream" (1444). He concludes: "Postcolonial analysis has to be brought up to date so that it can grapple with the fluidities and evasions of imperialisms no longer territorial" (1444). Bringing postcolonial analysis up to date to grapple with deterritorialization is turning attention to diaspora but will also necessitate thinking through comparisons that have as yet received little attention, such as those to which this current special issue is devoted.

If Rajan is correct in suggesting that globalization may well be a new and "perfected form of imperialism" (1444), then postcolonial literary criticism, because of its experience in identifying the rhetoric and management techniques of empire, may well be essential in identifying its globalizing practices and in suggesting modes for resisting or reorienting them. It is important to consider why globalization has captured the popular imagination in a way that postcolonialism never did. What conditions have made globalization a dominant discourse and postcolonialism a specialized academic discourse of limited public force? With the rise of globalization studies, culture assumes larger importance but in a redefined form that excludes or marginalizes the literary. The audience for literary criticism in particular continues to shrink. Although some recent scholarship implies that the social sciences alone may not be particularly wellequipped to deal with the complexity of globalization (Kalb \& de Land 274; Tomlinson), such recognitions have seldom led, as yet, toward establishing genuine dialogue with the humanities. The journal 
Nepantla: Views from South, established in 2000, seems designed to forward this goal: "to put in conversation different projects with common interests" (Mignolo, "Introduction": 4). Walter Mignolo's introduction to the first issue implies that "misplaced ideas" developed under modernity/coloniality need now to be "re-placed" (5) when knowledge production is placed in the service of social transformation.

The version of globalization that Nepantla critiques is well illustrated in Canadian William Watson's award-winning book, Globalization and the Meaning of Canadian Life. Watson makes only one reference to Canadian literature, to snidely dismiss its value. He argues: "the goods we are asked to subsidize-Canadian books, art, music, dance, theatre, cinema, and so on-are supposed to be vital to large numbers of Canadians, crucial components of their sense of themselves. Yet large numbers of Canadians evidently will not pay a premium beyond what the market charges for the American versions of these cultural products." Quoting the slogan of defenders of the arts with a sneer, he writes: "'They tell us who we are' ... but we will consume them only if someone else pays for them. Thus does the Toronto aesthete justify having his or her cultural diet financed by the great unwashed." It's interesting how Torontophobia is here used in a complex move to first conflate Toronto, elitism, and the arts and then to dismiss all three as parasites on the body of the nation, where to be the "great unwashed" is redefined as a badge of pride. Watson concludes: "if people will not pay a premium to read or hear or view stories about themselves...why should others pay on their behalf?" (245). Here individualism denies community in a world where monetary values reign supreme and the complex pleasures of the arts are reduced to the level of consumption implied through his choice of the words, "diet" "consume" and "product." Such is the Canadian face of globalization when defined as "neo-liberalism writ large" (Kalb: 9). This flawed logic is becoming the new "common sense" of many Canadians as the old nationalist defences of literature as the conveyer of identity break down under transnationalist pressures while alternative postcolonialist readings 
remain either too inaccessible or too threatening, perhaps, to take their place.

Yet postcolonial theory can help to contextualize such views because it works in a cross-disciplinary manner to reorganize knowledge more equitably, not as mastery but as inquiry, in a quest to think otherwise. Working from principles that accept local differences, postcolonial theorizing seeks a larger picture that can maintain respect for genuine difference while also drawing comparisons that link disparate fields within broader frames of analysis. Postcolonial theory investigates the global impact of colonialism on all those involved in its practices. It works to retrieve and revalue formerly subjugated knowledges, not as a search for self-validating myths of origin but in a search for missed opportunities for a fully cross-cultural dialogue to develop, dropped threads that might be picked up and rewoven into the modes of reconceptualizing local and global negotiations of understanding today. Neither an additive nor a reductive model, it challenges teachers in English to rethink how they understand literary history, literary value, and the place of literature in the world

Such a postcolonial approach identifies a specific genealogy behind contemporary global expansions. In Local Histories, Global Designs, Walter Mignolo argues that "behind the market as the ultimate goal of an economic project that has become an end in itself, there is the Christian mission of the early modern (Renaissance) colonialism, the civilizing mission of the secularized modernity, and the development and modernization projects after World War II. Neoliberalism, with its emphasis on the market and consumption is not just a question of economy but a new form of civilization" (21-2). To address the rising ascendance of such a concept, then, requires a complex civilizational investigation from a postcolonial perspective, with important historical and literary dimensions.

Before considering how to organize such a task, and the challenges it may pose to traditional disciplinary structures and methodologies, it is useful to distinguish between the implied definition of globalization 
as a concept, often conflated with "neoliberalism writ large," as Kalb puts it (9), and globalization as a complex and multilayered social phenomenon, for which many different explanatory theories are currently being advanced. The same confusing usage has plagued postcolonialism. Misao Miyoshi quips: "The term globalization is nearly as abused as postcoloniality" (248). In both cases, efforts to coin separate words for separate functions have not caught on-an interesting issue in itself. Nonetheless, it is possible to make some helpful distinctions about the multiple ways in which these indispensable terms are being employed. In globalization as phenomenon, then, many believe that "people and places in the world are becoming more extensively and densely connected to each other as a consequence of increasing transnational flows of capital/goods, information/ideas, and people" (Kalb, "Localizing Flows": 1). To what extent such increased flows are so major and different in kind as to constitute an entirely new phenomenon, to what extent they are continuous with earlier systems of capitalism or imperialism, or to what extent they merely represent the latest stage of development in the modern world system, are hotly debated questions that require further research to resolve. The task of globalization theory, as Tomlinson puts it, is "both to understand the sources of this condition of complex connectivity and to interpret its implications across the various spheres of social existence" (2). Tomlinson goes on to suggest that the multidimensionality of globalization "confounds" the conventional taxonomy of the social sciences, which is committed to breaking down human life into discrete categories (13).

Kalb extends this insight even further, arguing that "It was the neglect, denial, or even conscious repression, of institutional complexity, social relationships, contingency, and possible contradictions that made the concept into the ideological magnet it was soon to become" (8). But Kalb also speculates, together with Marco van der Land, that "popular awareness of culture's deep involvement in globalization studies... has probably helped to boost the new academic fields of cultural and 
postcolonial studies, including their ramifications within their mother social science and humanities disciplines" (227). Thus if literary studies appear to be weakened by globalization, postcolonial and cultural studies may well find themselves strengthened, if only within academic circuits of power. Little has yet been done to capitalize on such synchronicity of concern, however, or to consider the dangers attendant on such forms of strengthening.

Philip Darby notes that postcolonialism, surprisingly given its agenda, "has had practically no engagement" with international relations, globalization or dependency theory. "It has developed its own critical modes and specialized language. It has tended to rely on distinctive source materials. Its politics diverge sharply from those of mainstream international relations and globalization theory" (13). Despite this history, Darby argues that postcolonial perspectives can be helpful when brought to bear on these other practices. They will also be necessary for understanding the changing relation to global culture of Brazilian and Canadian literatures. That understanding must build on the work of critics such as Smaro Kamboureli and Roy Miki, to ask how Canadians may avoid "simply re-circulating" what Miki terms "the old systems of power" (107). A global frame of reference, informed by literary study in international and postcolonial contexts, and using Canada as a test case, may help in recasting the terms of discourse, both in discussing Canada's future as a nation and in responding positively to the challenges of globalization.

What are some of those old systems of power? In Canadian literary studies specifically, they are the terms in which national identity, indigenous issues, and multicultural policies have been presented and understood. New configurations of global flows offer critics the chance to shift literature away from its conventional constructions as somehow both autonomous and transcendent, on the one hand, and nationaffirming, on the other. At the same time, literary texts are exceptionally well constituted for presenting complex relationality in subversively non-threatening ways. Like Canadians, Brazilians are currently 
negotiating the new sets of questions to which postcolonial and globalization studies give rise. What is at stake in current theorizations of globalization? How does literary value change when viewed, first through postcolonial lenses, and then through those of globalization? When postcolonial methodologies are brought to bear on globalization, what do they reveal? How do the roles of the literary critic, the reader, and the public intellectual change when globalization becomes the new master discourse for the beginning of the twenty-first century? Many current Canadian fictional texts are also negotiating these questions, in ways that demonstrate a new receptivity to dialogue across the North/South divide. Two areas where postcolonial and globalization studies converge, with implications for Canada and Brazil, include the international organizing efforts of the world's indigenous peoples and the rethinking of African and Caribbean legacies within the Americas that has followed the publication of Paul Gilroy's The Black Atlantic. The experiences of globalization may have made the academy more receptive to the diasporic rethinking of modernity attempted in Gilroy's charting of the black Atlantic but they may also be contributing to revivals of the kind of "indigenous fantasy," described by Marc Auge as "that of a closed world founded once and for all long ago" (44).

Okanagan writer Jeannette Armstrong lodges many of these issues within the fabric of her novel, Whispering in Shadows. Her protagonist, Penny Jackson, a visual artist, jots ideas in her diary that are interspersed throughout the narrative. One of Penny's poems characterizes the conflation of imperialism, capitalism and globalization as "a global design of conjure and conquer." Unpacked, this simple phrase evokes Noam Chomsky's model of the "manufacture of consent," Antonio Gramsci's theorization of the operations of hegemony, and Louis Althusser's notion of "interpellation" as part of the conjuring that enables conquering. Yet "conjure" also implies that "there's magic in the web of it" (Othello), a power deriving from forces of irrational fear and desire, and possibly even some supernatural influence. Global 
designs cannot be reduced to economics and its implied characterization of human actors as motivated by "informed self-interest" alone.

Throughout this paper I juxtapose the imagery of poetry and fiction against the abstract language of academia in an attempt to push understanding of what one recent critical anthology terms, "the ends of globalization" (Kalb); that is, beyond the abstract back into the human impact of these processes, not the termination but the point of globalization. So first I will turn to a sensory image, created through the words of this poem in Armstrong's novel:

\author{
Poem from her Diary \\ Globalization \\ something about breathing \\ in the dirty \\ buzz words \\ and missed manners \\ of a global design \\ of conjure and conquer \\ situating the hilarity as common text \\ a mastering and the master class \\ I imagine Coyote \\ standing on a marble pedestal \\ fifteen feet above \\ is he holy \\ as he is trying to see how far \\ his piss will arc into space \\ a golden connection \\ to the big mother \\ his features \\ exquisitely executed
}




\author{
in blue veined alabaster \\ an icon \\ in a temple constructed \\ for his worship \\ poems and prose \\ scattered at his feet \\ and song filling the air \\ dedicated to him... \\ and Coyote pissing around (Armstrong 2000:151-2)
}

Poems continue to speak to people in ways beyond the reach of a reductively rational logic. Literary scholars can address globalization processes through the condensation of events provided in literary texts, bringing a holistic perspective to the global/local dyad that currently dominates globalization discourse. And they can bring such processes down to earth in ways that make them accessible to wider audiences. The complexities of this poem provide a good example of such strengths.

Arjun Appadurai suggests that "One of the biggest disadvantages faced by activists working for the poor in fora such as the World Bank, the U.N. system, the WTO, NAFTA, and GATT is their alienation from the vocabulary used by the university-policy nexus (and, in a different way, by corporate ideologues and strategists) to describe global problems, projects, and policies. A strong effort to compare, describe and theorize 'globalization from below' could help to close this gap" (2000:17). In a manner memorably analysed by Peter Stallybrass and Allon White in The Politics and Poetics of Transgression, Armstrong's trickster Coyote mixes high and low, verbal play and bawdy humour, lodging serious critique within a comic, but sharp-edged, visual image. Armstrong's poem is ideally suited to theorizing the complexity of everyday life, feeding into the analysis of globalization from below. These perspectives need to be combined with "globalization from above," the analysis of global institutions, their practices and their 
regulation, to provide a full picture. But the novel, and the poem, can theorize them together as this poem does.

Appadurai also suggests that "collaborative research on globalization could contribute to new forms of pedagogy (in the sense of Freire 1987)" (2000:17). Armstrong's novel is deliberately pedagogical in this sense. In Armstrong's poem, the over-reaching arc of Coyote's piss flowing into a visual image of Macdonald's golden arches provides an amusingly apt, though also chilling, image for globalization as a new religion. It reverses the move from thinking in terms of fixed structures to disjunctive flows (theorized as central to globalization processes by critics such as Appadurai in Modernity at Large). Here the flow is frozen into the arch, implicitly questioning the liberatory rhetoric of globalization while maintaining its stress on connectivity. It mocks the positing of competition as the basis for progress - how far can Coyote send his piss out into the world? It mocks globalization as the new religion of capitalism. And it employs a carnivalesque irreverence that challenges the self-righteous triumphalism of globalization as presented by its neoliberal advocates.

The poem also enacts an implicit collision between social science theses that construct 'McDonaldization' as an explanatory and interpretative frame, on the one hand, and indigenous modes of systemic thinking, on the other. George Ritzer's McDonaldization thesis "claims that rationalized capital intensive forms of production, distribution, marketing, and consumption are conquering older or alternative forms of provision everywhere in the world. The same specter is evoked by Benjamin Barber (1996) who fears that there might be little public choice between this sort of 'McWorld' and its territorialist and parochial opposite, symbolized, for him, by the Jihad and ethnic cleansing" (Kalbe \& van de Land: 278). Postcolonial theory and indigenous coyote aesthetics reject the binary model of Barber's thesis, while effectively reversing, and recontextualizing, Ritzer's version: Where Ritzer sees McDonaldization conquering older and alternative forms of provision, Armstrong sees this process as yet another in the series of what Tom 
King might call Coyote's mistakes. Unlike Armstrong, I don't find the McDonaldization thesis a fully persuasive account of contemporary trends, nor do I share her view that this trend can be rectified by a return to older and alternative forms of provision as practiced by indigenous peoples, but I do appreciate her posing of the terms of the debate in such an accessible pedagogical form.

For me, Whispering in Shadows is at its strongest in posing a series of debates around what constitutes globalization and how it might be countered. Penny's partner, David, the global activist for indigenous people's rights whose travels provide a global context for Penny's local vision, believes that "Your grief is where the hope resides" (188). The novel seems to endorse this view, suggesting that things will get worse before they get better. While the earth will eventually regain its balance, it might be too late for humanity as a species. The novel argues that the "mastering" discourses propelling globalization have lost sight of the human "ends of globalization." Working as a theorist, Appadurai (2000) makes a similar point, suggesting that globalization challenges academics to rethink "research" itself, redirecting its focus to "the problems of the global everyday" (18), a move already advanced in books such as Linda Tuhiwai Smith's Decolonizing Methodologies: Research and Indigenous Peoples, where the indigenous research agenda is remapped as a complex series of interlocking circles, with self-determination at its center (Figure 6.1:117).

In a parallel move, Walter Mignolo argues for the need to reconceptualize "theory" in order to "delink" it from past associations and, he implies, to include the analysis offered in novels such as Armstrong's. Mignolo believes that we need to "delink the concept of theory from its modern epistemological version (to explain or to make sense of unconnected facts or data) or its postmodern version (to deconstruct reified conceptual networks.)" He argues that "One of the aims of post/Occidental/colonial theorizing....is to reinscribe in the history of humankind what was repressed by modern reason...If postcoloniality is not able to break away from modern epistemology, it 
would become just another version of it with a different subject matter. It would be, in other words, a theory about a new subject matter but not the constitution of a new epistemological subject that thinks from and about the borders" (110). What might this new subject, who thinks from and about the borders, look like? How might this subject think?

Armstrong's Penny may be read as constituting just such a subject in formation, although she needs to fall ill with the cancerous rage and despair of fighting the combined effects of colonialism and globalization before she realizes that to combat these ills she cannot stand directly against them but must relearn how to stand beyond them, thinking and feeling from the center of her Okanagan heritage, which still survives on the borders of the dominant. I see this stand as roughly similar to Homi Bhabha's invocation of postcolonial theory as a theory of the "beyond" and to Paul Gilroy's argument in Against Race: Imagining Political Culture Beyond the Color Line, where he worries that the dangers of race-thinking may well survive in anti-racist activity that wishes to demolish race-thinking while continuing to depend upon it.

The critical reception of Armstrong's novel reveals the limitations of conventional literary criticism in responding to such innovative engagements with globalization and its discontents. The reviewer in the July 1, 2000 issue of Quill and Quire writes, in a manner typical of the reception of Armstrong's fiction, that "Penny is an explain-it-all narrative device rather than a nuanced character" and complains that the book "does not present a world, just ideas in the abstract." I haven't the time fully to counter this view here although such a countering must take place. The novel of ideas has not fared well in Canadian literary criticism. But this is a novel that roots its ideas in a deeply felt relation to place and community. Indigenous peoples construct character in terms of "all my relations" rather than in terms of the individuated, autonomous self. Characterization therefore assumes different norms and values and provides different understandings of how character may be viewed. It isn't just a question of turning Western aesthetics on its head, substituting an indigenous for a Western realist aesthetic. 
Rather, in Wilson Harris's terms, it is necessary to replace the novel of "consolidation," "which serves ultimately to consolidate one's preconception of humanity" (40) and to promote a "vested interest in a fixed assumption and classification of things" (33) with the novel of "fulfillment," where "the sovereign individual" (34) is rejected in favour of "a visionary character of fulfillment...realized in experiment instinctive to the native life and passion of persons known and unknown in a structure of time and space" (34-5). Whispering in Shadows seduces the reader into its world, enabling insight into Penny's dilemmas while refusing the pleasures that many may expect to experience through identification with a central literary character. Penny's experiences are not available for readerly appropriation but they are dramatized with considerable complexity in non-consolidating fashion. In light of strong pressures from white Canadian society to identify with indigenous others, this resistence to readerly identification takes on political force. As Graham Huggan argues, the urge to identify with indigenous life stories "often comes at the expense of knowledge of cultures/cultural groups other than its own" (17). Armstrong's characterization of Penny resists the exoticism that is bound up, "not just in the perception of cultural difference but in the sympathetic identification with supposedly marginal cultural groups" (17).

In 1997 Armstrong published an article in The New Internationalist that demonstrates, through its imagery and its argument, the close relationship between Armstrong's views and those of Penny in the novel. Armstrong's diagnosis of the sickness of contemporary society, which she links to colonizing and other globalizing practices, employs an Okanagan word that roughly translate into English as "people without hearts" (1). ${ }^{2}$ She fears for humanity because without the lifegiving connections to land and people, one becomes "simply flesh waiting to die" (2). She concludes: "it is in the matter of the heart where we must reconstruct" (2). The human as zombie; the body politic in need of reconstructive heart surgery - these images lead me into the very different narrative of Nalo Hopkinson's fantasy retelling of the 
Caribbean folk tale of Ti-Jean and his brothers in Brown Girl in the Ring.

Set in the city core of Metro Toronto in the near future, the novel explains that "When Toronto's economic base collapsed, investors, commerce, and government withdrew into the suburb cities, leaving the core to decay" (4). "When an inner city collapses and people run to the suburbs," the protagonist learns, people call it a "doughnut hole" (10-11). This hole where the heart of the body politic should beat has been caused by events memorialized in a series of familiar headlines, referring to native land claims, international trade embargoes, federal government cuts in transfer payments, jumping jobless rates, budget cuts forcing downsizing, jobs leaving Toronto, rapid transit breakdowns and riots in the streets. These combined pressures have torn the heart out of Toronto, which is now ruled by an evil gang lord who employs obeah, zombies and duppies to maintain his power.

In the traditional story, Ti-Jean, partnered by his brothers, GrosJean and Mi-Jean, employs his cleverness to beat opponents more powerful than himself. Hopkinson changes the gender of the protagonists and their family relationship. Here Ti-Jeanne, her mother Mi-Jeanne, and her grandmother, Gros-Jeanne, must employ their wits (and their guts) to defeat the obeah (wielded by the man who is their grandfather, father and ex-husband respectively) and restore the appropriate balance connecting the realms of the powerful spirit ancestors, the middle ground of the living, and the world of the dead. The $\mathrm{CN}$ tower becomes the resonant symbol through which this goal is accomplished. The tower derives its name from the Canadian National Railway, mythologized through much of the twentieth century as the agent realizing "the national dream" and popularized in a trilogy of that title by Pierre Berton. The horizontal line of the railway linking East to West is reconceived as the CN Tower, an instant tourist symbol for downtown Toronto and a vertical link between earth and sky, which in a now outdated technology links the world in dispersed rather than linear fashion. Hopkinson reconfigures this well known landmark as 
the world's center pole, a "the bridge between the worlds" of the living, the dead, and the gods who ruled them: "Like the spirit tree that the center pole symbolized, the CN Tower dug roots deep into the ground where the dead lived and pushed high into the heavens where the oldest ancestors lived. The tower was their ladder into this world" (221). Here the "conjure and conquer" strategies of obeah feed on the destruction brought about by globalization until the healing conjuring of the youngest woman restores the heart of the city to community ownership.

In a parallel fashion, Gros-Jeanne's heart, which has literally been ripped from her body to serve as a transplant for the ailing Premier of the province, invades and takes over the Premier's body and brain. When Premier Uttley awakens, she is literally "a new woman now" (237), transformed from neo-liberal autonomous subject into a human being with a social conscience and the habit of muttering to herself in Caribbean slang. Her new black heart now runs the province through the medium of her white body, changing government policy on organ transplants and designing plans to "rejuvenate Toronto" (239). Even global trading in body parts, it seems, can be strategically turned from victimization into one of the new weapons of the weak. If only it were that simple; yet the novel does attest to the healing and inspiring role of fantasy as itself a form of global intervention.

This text negotiates black urban, black Canadian, diaspora, and global discourses, recognizing them as overlapping and potentially complicitous fields. Like Armstrong's novel, Brown Girl works through identity politics to come out the other side, with a vision that encompasses humanity, while insisting that new norms be agreed-upon for constituting the human and new directions be found for structuring and strengthening communities. The spiritually grounded return of these two texts, the first rooted in indigenous and the second in Black Atlantic forms of belonging, pose purposeful challenges to the mainstream models for mapping Canadian identity and for rethinking its belonging within the Americas. If the Canadian literature of 
nationality can be seen to follow the same narrative patterns that Wasserman identifies in the literatures of Brazil and the United States from 1830 to 1930 , including a general reliance on marriage plots to tell of "implanting civilization in the American natural world" (5), then both these texts are adamant in their rejection of the marriage plot.

Their contributions to globalization studies are harder to assess. Each balances the need to return to more holistically grounded spiritual systems beside a faith in local economic initiatives as a counter to transnational capitalism. Hopkinson's happy ending shows the Premier of Ontario about to offer "interest-free loans to small enterprises that are already there," grounded in the mis-named "rat hole" of the city core (240). This sounds very similar to the "deglobalization" policies advocated at the second annual World Social Forum, held in Porto Alegre, Brazil, in January 2002. Armstrong's text categorically rejects the city, seeing only hell where Hopkinson sees potential for renewal through the forging of alliances amongst and across differently constituted multicultural groupings, street kids, the homeless, and the other survivors who refuse to abandon the city core. Armstrong's belief that local control will be the first step in solving many local, national, and global problems, is based primarily in the traditional values of isolated rural communities (108). Real community, for Armstrong, can only be based on blood and land (274), a vision difficult to translate from Okanagan, in which Armstrong explains "We also refer to the land and our bodies with the same root syllable" (1996:465) into English, where these words carry very different resonances. For Hopkinson, nurturing communities are stronger when built on affinities of value and interest, and can be readily created across ethnic, religious, and other ties. As in the traditional Ti-Jean stories, Ti-Jeanne's helpers emerge from among everyone that she has ever helped. Her grandfather, despite their blood tie, is the enemy she must defeat to restore the integrity of her multicultural community, which in a sense, embodies the global in its local sphere. This is very close to the multicultural Toronto boosterism currently employed to bolster Toronto's Olympic bid, yet there is a 
grain of truth in the picture too. Critics of Canada's still dominant model of the multicultural mosaic may well feel bemused to see this metaphor of the mosaic revived within the anti-globalization movement that has now met twice in Porto Alegre, Brazil.

Armstrong's text locates the local within global circuits of power in a fashion different from that employed by Hopkinson. She identifies globalization as continuous with imperialism, criticizing the United Nations for upholding racist principles that fail to recognize the sovereignty of First Nations (146-7). She endorses the Indigenous Organizations for Regional Autonomy and Indigenous Fair Trade initiatives as viable ways to make local voices heard on the global scene. Hopkinson conjures spiritual powers to defeat the chaos that comes from unfettered capitalism, but her real point may be that the folk wisdom passed on by her African ancestors can play a role in restoring the human environment in Canada. Armstrong too believes that education in previously discounted traditional modes of knowledge can make a difference in combating the evil that "we have conjured on the earth" (247) through out of control consumerism and disregard for the environment. Penny believes that "People who live in the relative comforts of this country can't know, unless we make sure they know" what the effect of their local decisions may be on people in other localities (149). "We are at war," she muses, "The trouble is we don't recognize the enemy. We buy the stuff that causes it" (246). When she is stricken with cancer, most likely caused by an early job spraying apples with pesticides in the Okanagan, she sees herself as "a human price" paid for so-called progress (243). She feels personally sickened by accounts of Mexico/US border sweatshops; organs for sale; kidnapped children; poverty throughout the Americas (165) as Mayan cooperatives are shut out of the markets as a result of NAFTA and villagers are forced to sell out common lands to outside privatization $(168 ; 176)$. Worst of all, she feels a "rage of complicity, simply by being." "We get tainted with that blood without even realizing it and without knowing its effect somewhere else" (189), she laments. But she also believes, with 
postcolonial theorists, that "Breaking the illusion of western development and progress as a world order is critical to changing it" (189-90).

It is this idealistic, possibly utopian, goal that motivates postcolonial analysis of literary texts and of globalizing movements. Such activity is insufficient on its own, but it is making inroads in the theorizing of literary history and national literatures. Although Edward Said (as summarized by Giles Gunn in the PMLA special issue), deplores "the absence of any compelling alternative model that would permit the humanities to mount "an effective critique of globalization's most terrible excesses" (23), these alternative models do exist in literary texts such as these and in the postcolonial critique that is learning to interpret them. Such effective analysis is a first step toward effective action. Contrary to Said's pessimism, such work is attempting to "discern where the real sites of resistance are" (Gunn 23). Said believes that "an autonomous aesthetic realm exists" (64), possibly "in dialectical tension with the administered culture of markets, as well as with globalized buying and selling" (67). These texts explore that relation and question that autonomy. They are creating new models of complex interconnectivity, redrawing the historical geography of the modern world system to focus on complex oceanic intercontinuities such as the Black Atlantic and the Pacific Rim and on the continental flows that link indigenous peoples throughout the Americas. Far from seeing "these new questions about the relation between parts and whole, between local and general, between individual and collective" as a "problem" (23), as Said and Gunn claim, I see them as the challenges simultaneously posed by these Canadian texts to the conventional modes of reading, categorizing, and valuing texts within English literary studies and to the dominant literary discourses about globalization, which Rey Chow argues merely reiterate "the traditional modernist narrative of the West" (as summarized in Gunn:23). Creative artists and literary critics are interrupting these reiterated narratives, but Canadian workers in the humanities need to collaborate across 
traditionally constituted institutional boundaries, with our colleagues in Brazil and with our colleagues in the social sciences, to ensure that our voices are heard.

\section{Notes}

1. I wish to thank the graduate student organizers, Andrea Mus and Daniel Martin, who invited me to deliver an earlier version of this paper at the Literary Studies and Global Culture conference held at the University of Victoria in March 2001. Their feedback was helpful as I began this work. I am also grateful to the Social Sciences and Humanities Research Council of Canada for a research grant on Postcolonialism: The Critical Heritage, which helped fund this research.

2. See also her chapter, "'Sharing One Skin': Okanagan Community" in The Case Against the Global Economy: And For a Turn Toward the Local, ed. Jerry Mander and Edward Goldsmith. San Francisco, 1996. 460-70.

\section{Works Cited}

Appadurai, Arjun. "Grassroots Globalization and the Research Imagination." Public Culture 12 (1) 2000: 1-19.

. Modernity at Large: Cultural Dimensions of Globalization. Minneapolis: University of Minnesota Press, 1996.

Armstrong, Jeannette. "Sharing one skin: native Canadian Jeannette Armstrong explains how the global economy robs us of our full humanity." New Internationalist. January-February 1997, vol no 287: 16-17.

. "'Sharing One Skin': Okanagan Community." The Case Against the Global Economy and For a Turn Toward the Local, ed. Jerry Mander and Edward Goldsmith. San Francisco: Sieera Club, 1996. 460-70.

Whispering in Shadows: a novel. Penticton: Theytus, 2000. Auge, Marc. NonPlaces: Introduction to an Anthropology of Supermodernity. Trans. John Howe. London: Verso, 1995. 
82 Diana Brydon

Bamyeh, Mohammed A. The Ends of Globalization. Minneapolis: University of Minnesota Press, 2000.

Barber, Benjamin, and Andrea Schulz, eds. Jihad Versus McWorld. New York: Ballantine, 1996.

Brydon, Diana. "Detour Canada: Rerouting the Black Atlantic, Reconfiguring Canada." Unpublished paper delivered at the Postcolonial Reconfigurations conference at the Universite de Bruxelles Libre, Belgium, in November 2001.

. Postcolonialism: Critical Concepts in Literary and Cultural Studies. London: Routledge, 2000.

_."Re-Routing the Black Atlantic." Topia 5 (Spring 2001): 94-100

Chow, Rey. "How (the) Inscrutable Chinese Led to Globalized Theory." PMLA 116.1 (January 2001): 69-74.

Crosby, Alfred W. Ecological Imperialism: The Biological Expansion of Europe, 9001900. Cambridge: Cambridge University P, 1986.

Darby, Phillip, ed. At the Edge of International Relations: Postcolonialism, Gender and Dependency. London: Pinter, 1997.

Dunn, Christopher. Brutality Garden: Tropicalia and the Emergence of a Brazilian Counterculture. Chapel Hill: U of North Carolina P, 2001.

Freire, Paulo. Pedagogy of the Oppressed. New York: Continuum, 1987.

Gilroy, Paul. Against Race: Imagining Political Culture Beyond the Color Line. Cambridge, Mass: Belknap Press of Harvard University Press, 2000.

The Black Atlantic: Modernity and Double Consciousness. Cambridge, Mass: Harvard University Press, 1993.

Gray, John. "Goodbye to globalization" The Guardian Weekly. 2001.3.11/ 200103081301.

Gunn, Giles. “Introduction.” PMLA 116.1 (January 2001): 16-31. 
Jameson, Fredric and Masao Miyoshi, eds. The Cultures of Globalization. Durham: Duke University Press, 1998.

Harris, Wilson. Tradition, The Writer and Society. London: New Beacon, 1967.

Hopkinson, Nalo. Brown Girl in the Ring. New York: Warner, 1998.

Huggan, Graham. The Post-Colonial Exotic: Marketing the Margins. London: Routledge, 2001.

Kalb, Don, et al., eds. The Ends of Globalization: Bringing Society Back In. Lanham, Maryland: Rowman \& Littlefield, 2000.

Kalb, Don. "Localizing Flows: Power, Paths, Institutions, and Networks." The Ends of Globalization. 1-29.

Kalb, Don and Marco van der Land. "Beyond the Mosaic: Questioning Cultural Identity in a Globalizing Age." The Ends of Globalization. 173-180.

Kamboureli, Smaro. Scandalous Bodies: Diasporic Literature in English Canada. Toronto: Oxford University Press, 2000.

Larsen, Neil. Determinations: Essays on Theory, Narrative and Nation in the Americas. London: Verso, 2001.

Reading North by South: On Latin American Literature, Culture and Politics. Minneapolis: U of Minnesota P, 1995.

Mignolo, Walter D. "Introduction: From Cross-Genealogies and Subaltern Knowledges to Nepantla." Nepantla: Views from South 1.1 (2000): 1-8.

. Local Histories/Global Designs: Coloniality, Subaltern Knowledges, and Border Thinking. Princeton: Princeton University Press, 2000.

Miki, Roy. Broken Entries: Race Subjectivity Writing: Essays. Toronto: Mercury, 1998.

Miyoshi, Masao. "'Globalization,' Culture, and the University." The Cultures of Globalization. 247-70.

PMLA. Special Topic: Globalizing Literary Studies. 116.1 (January 2001). 
84 Diana Brydon

Pratt, Mary Louise. Imperial Eyes: Travel Writing and Transcultuation. New York: Routledge, 1992.

Rajan, Balachandra. "Globalization and Imperialism." PMLA Forum. 116.5 (October 2001): 1444-5.

Ritzer, G. The McDonaldization of Society. Thousand Oaks, Calif: Pine Forge, 1993.

Said, Edward W. "Globalizing Literary Study." PMLA 116.1 (January 2001): 64-8.

Sandoval, Chela. Methodology of the Oppressed. Minneapolis: U of Minnesota P, 2000.

Schwarz, Roberto. Misplaced Ideas: Essays on Brazilian Culture. Ed. John Gledson. New York: Verso, 1992.

Stallybrass, Peter and Allon White. The Politics and Poetics of Transgression. New York: Cornell UP, 1986.

Szeman, Imre. "Belated or Isochronic? Canadian Writing, Time, and Globalization." Essays on Canadian Writing 71 (Fall 2000): 186-94.

Tomlinson, John. Globalization and Culture. Chicago: University of Chicago Press, 1999.

Tuhiwai Smith, Linda. Decolonizing Methodologies: Research and Indigenous Peoples. London: Zed, 1999.

Wasserman, Renata R. Mautner. Exotic Nations: Literature and Cultural Identity in the United States and Brazil, 1830-1930. Ithaca: Cornell UP, 1994.

Watson, William. Globalization and the Meaning of Canadian Life. Toronto: U of T Press, 1998. 